\title{
MEMBANGUN KECERDASAN FINANSIAL DENGAN MATEMATIKA KEUANGAN
}

\author{
Yulia Romadiastri ${ }^{1}$
}

\begin{abstract}
Abstrak
Setelah IQ (Intellectual Quotient), EQ (Emotional Quotient), SQ (Spiritual Quotient), sekarang muncul FQ (Financial Quotient) atau biasa disebut kecerdasan finansial. Hal ini dikarenakan salah satu cabang dalam ilmu keuangan yang berkembang pesat dalam beberapa tahun belakangan ini adalah perencanaan keuangan atau financial planning. Pada prinsipnya merencanakan keuangan yang baik itu mudah dan semua orang dapat melakukannya sendiri. Untuk dapat melakukannya, seseorang hanya perlu memahami matematika keuangan dan memiliki pengetahuan tentang produk pasar modal dan pasar uang yang tersedia. Pemahaman akan matematika keuangan membuat seseorang menjadi cerdas finansial dan memungkinkan untuk menyusun sendiri perencanaan keuangannya.
\end{abstract}

Kata kunci: kecerdasan finansial, matematika keuangan, perencanaan keuangan.

\footnotetext{
${ }^{1}$ Dosen Tadris Matematika Fakultas Tarbiyah IAIN Walisongo Semarang
} 


\section{Pendahuluan}

Kecerdasan seringkali dikaitkan dengan IQ (Intellectual Quotient) yang dianggap sebagai satu-satunya tolok ukur kecerdasan seseorang. Mereka yang memiliki IQ tinggi akan dianggap mempunyai peluang besar untuk menjadi orang yang sukses. Ini adalah paradigma lama yang sudah tidak relevan lagi untuk dianut pada saat ini. Karena telah banyak bukti yang menunjukkan bahwa mereka yang meraih prestasi sekolah kurang bagus ternyata bisa menjadi orang sukses. Akan tetapi, bisa tidaknya seseorang menjadi sukses salah satunya adalah bergantung pada kemampuannya melakukan perencanaan keuangan dan mengelolanya.

Perencanaan keuangan sebaiknya dilakukan oleh semua orang, baik yang memiliki banyak atau sedikit uang. Memiliki banyak uang tanpa perencanaan keuangan, bisa membuat kekayaan menjadi terkikis habis. Sebaliknya, memiliki sedikit uang tanpa perencanaan, bisa membuat kekayaan tidak bertambah bahkan kian terjebak dalam pusaran arus utang. ${ }^{2}$ Untuk melakukan perencanaan keuangan seseorang dituntut untuk mempunyai kecerdasan dalam mengelola pendapatan (uang). Kecerdasan dalam mengelola uang inilah yang sekarang lebih banyak dikenal dengan istilah Kecerdasan Finansial. Pendidikan untuk memperoleh kecerdasan finansial ini sangat penting bagi semua orang, tak terkecuali golongan ekonomi menengah ke bawah agar mereka mampu meningkatkan taraf hidupnya.

Perencanaan keuangan tidak semata-mata hanya mengatur pengeluaran sama dengan atau bahkan tidak lebih dari pendapatan tapi juga mampu untuk mengelola sumber daya baik di dalam dirinya sendiri maupun diluar dirinya untuk menghasilkan suatu nilai yang dalam hal ini diukur dengan uang. Kecerdasan finansial adalah kemampuan seseorang untuk mendayagunakan kemampuan pribadinya dalam mendapatkan dan mengelola uang. Tidak ada jaminan bahwa seseorang yang ber-IQ tinggi memiliki kecerdasan finansial yang tinggi pula.

${ }^{2}$ Hidayat, Taufik.2010. Financial Planning; Mengelola \& Merencanakan Keuangan Pribadi dan Keluarga. Mediakita: Jakarta.

100 Jurnal PHENOMENON, Volume 1 Nomor 1, Juli 2011 
Secara umum, kecerdasan bisa dikembangkan baik melalui institusi pendidikan formal maupun non formal. Disinilah letak peran matematika, kecerdasan finansial seseorang dapat dibangun dengan mempelajari matematika, khususnya matematika keuangan. Menurut Budi Frensidy, dengan menguasai matematika keuangan akan sangat membantu seseorang menjadi cerdas finansial. $^{3}$

\section{Kecerdasan Finansial}

Ketika baru lahir, manusia sama sekali tidak bisa memenuhi seluruh kebutuhan hidupnya. Dimulai dari makan, minum, pakaian, perawatan, tempat tinggal dan semuanya masih disediakan oleh orang lain yaitu orangtua atau pengasuhnya. Semua kebutuhan tadi dapat dirupiahkan, bahkan termasuk makanan yang sudah siap di piring pun belum akan bermanfaat bagi seorang bayi kecuali ada orang lain yang menyuapkannya. Tenaga untuk menyuapi si bayi pun dapat diuangkan berupa gaji seorang pengasuh. Pendek kata, semua bisa dinilai dengan uang. Misalkan seluruh kebutuhan seorang bayi setelah diuangkan adalah Rp. 1 juta perbulan. Kemudian karena si bayi sama sekali tidak mampu berperan untuk memenuhi Rp. 1 juta, maka kemampuan si bayi untuk menghasilkan uang atau segala sesuatu yang dapat dinilai dengan uang untuk kebutuhan dirinya sendiri adalah nol. Dengan demikian, kecerdasan finansial si bayi adalah nol yang diperoleh dari nilai rupiah yang bisa dihasilkan dengan jerih payahnya sendiri dibagi dengan nilai rupiah dari seluruh kebutuhannya. ${ }^{4}$

Semakin bertambah usia, si bayi akan banyak belajar dan mulai mempunyai kemampuan untuk menghasilkan sesuatu dan mengurangi ketergantungannya sehingga mampu memenuhi berbagai kebutuhannya. Pada suatu saat, ketika seluruh kebutuhannya dapat dipenuhi dengan jerih payah sendiri kecer-

\footnotetext{
${ }^{3}$ Frensidy, Budi. http:/ / suhaplanner.wordpress.com/2010/08/10/ siasati-tingginya-kpr-bank/. Diunduh 2 April 2011

${ }^{4}$ Supriyono, Iman. http:/ / www.snfconsulting.com/artikel03.html. Diunduh 5 April 2011
} 
dasan finansialnya menjadi satu. Misal saat SMU kebutuhan si A perbulan sekitar Rp.400.000,-. Kemudian si A mempunyai usaha sambilan berjualan makanan kecil di kelas dan mendapat penghasilan bersih Rp.50.000,- sebulan. Maka skor kecerdasan

finansial si $A(F Q)=\frac{50000}{400000}=0,125$. Selanjutnya ketika si A kuliah, kebutuhannya meningkat menjadi Rp.600.000,- sebulan. Tapi ketika si A kuliah, ia telah memiliki banyak link, sehingga usaha jualan makanan kecil di kelas meningkat menjadi jualan di kos-kosan, ia cukup menitipkan di kost teman-temannya dan di warung-warung terdekat. Dan penghasilan bersihnya meningkat menjadi Rp.150.000,- per bulan, maka skor FQ si A $\quad=\frac{150000}{600000}=0,25$. Usaha si A terus berlanjut, hingga akhirnya menjadi agen makanan kecil yang cukup mapan, dan punya jaringan yang lebih luas sehingga penghasilan per bulan Rp.600.000,-. Yang akhirnya skor FQ si A $=\frac{600000}{600000}=1$. Skor 1 menandakan skor kemandirian atau juga disebut sebagai skor independensi. ${ }^{5}$

Mencapai kecerdasan finansial sama dengan 1 adalah sebuah pertanda kedewasaan yang intinya adalah pada bagaimana memenuhi kebutuhan hidup secara mandiri. Tetapi tentu saja tidak cukup hanya dengan memiliki skor 1 , karena manusia selalu ingin meningkatkan taraf hidupnya melalui pengembangan aset-aset yang dimiliki baik dengan menabung atau berinvestasi, sehingga usahanya akan semakin berkembang. Inilah perlunya meningkatkan skor kecerdasan finansial menjadi lebih dari satu. Bila mayoritas penduduk negeri ini telah mencapainya, semestinya Indonesia akan menjadi negara yang makmur dan masalah kemiskinan dapat teratasi.

${ }^{5}$ Astuti, Nunik Dwi. http://niex-klaten.blogspot.com/2006/07/ mengukur-fq-financial-quotient.html. Diunduh 5 April 2011.

102 Jurnal PHENOMENON, Volume 1 Nomor 1, Juli 2011 
Menurut Bustanul Arifin, kunci utama untuk menjadi cerdas secara finansial adalah pada pola keseimbangan antara bagaimana mendapatkan (inflow) dan menggunakan (outflow). Formula umum yang sering digunakan adalah 10:10:80. Bagian pertama $(10 \%)$ adalah prosentase yang dialokasikan untuk sedekah, walau bagaimanapun ini adalah hal yang penting. Bagian kedua $(10 \%)$ dialokasikan untuk investasi dunia dengan cara terus menanamkan modal guna pengembangan usaha berikutnya (bisa dengan tabungan di bank, pembelian saham, atau bentuk investasi lainnya yang sehat dan wajar). Sedangkan, bagian ketiga ( $80 \%$ ) digunakan untuk aktivitas itu sendiri, baik sebagai biaya operasional, pemeliharaan, dan kegiatan lainnya. Formulasi ini dianggap yang paling minimal untuk tetap menjadi cerdas secara finansial. ${ }^{6}$

Kecerdasan finansial adalah kemampuan untuk mengenali, menciptakan dan mempraktekkan sistem atau cara untuk mengakumulasi aset. Menurut William Tanuwidjaja, intisari dari formula kecerdasan finansial adalah: ${ }^{7}$

1. Memilah tujuan Produktif dan Konsumtif Tindakan seseorang sehari-hari yang bersifat mengeluarkan uang, dapat dikategorikan ke dalam dua jenis; Produktif dan Konsumtif. Setelah diamati ternyata 90\% item kegiatan kebanyakan orang adalah aktifitas konsumtif.

2. Membedakan Aset dengan Liabilitas Pelajaran terpenting dari seorang pakar kecerdasan finansial seperti Kiyosaki adalah teorinya untuk memisahkan antara Aset dengan Liabilitas. Aset adalah harta yang dapat mendatangkan income, sementara Liabilitas adalah harta yang menguras income. Banyak Liabilitas yang tampak seolah-olah sebagai Aset, sehingga seseorang merasa kaya, walau sebenarnya miskin.

3. Memahami Aliran Uang

${ }^{6}$ Arifin, Bustanul. http:/ / bustanularifin.wordpress. com/2006/02/28/kecerdasan-finansial/. Diunduh 5 April 2011

${ }^{7}$ Tanuwidjaja, William. 8 Intisari Kecerdasan Finansial. Penerbit MedPress, Yogyakarta. 
Orang yang cerdas secara finansial, mampu melihat apa yang tidak dapat dilihat orang awam. Banyak pemain bisnis properti yang mencari emas tersembunyi. Mereka mencari lahan yang tidak ada nilainya bagi orang lain. Mereka menciptakan lingkungan dan menjualnya dengan mudah.

\section{Memiliki Daya Ungkit}

Daya ungkit adalah sesuatu yang membuat aset tumbuh berlipat ganda mengikuti deret waktu. Seorang tukang bakso yang ingin melipat gandakan omzetnya menjadi $200 \%$, ia bisa membuka cabang, termasuk melatih karyawan dan stafnya, menstandarisasi resep dan membuat tampilan outlet dengan ciri khas tertentu. Tak kalah penting, lokasi-lokasi yang dipilih pun harus tepat.

5. Biarkan Uang Bekerja

Kalau sistem sudah bekerja dengan baik, kini waktunya untuk beternak uang. Uang hasil jerih payah selama ini, sudah waktunya menjadi aset utama yang memberikan uang tunai. Caranya dengan menyebarkan uang tersebut ke berbagai instrument investasi menurut skala risiko yang diinginkan, guna menghindari total loss. Sehingga akan diperoleh keuntungan pada saat membeli, bukan pada saat menjual.

\section{Ciptakan Aset yang Tidak Bisa Dicuri Orang} Sangat diperlukan untuk menciptakan aset yang tidak bisa dicuri, hilang atau dirampok. Yaitu cara berpikir dan cara bertindak. Boleh saja bangkrut total, namun jika masih mempertahankan cara berpikir dan bertindak cerdas secara finansial, maka semua yang hilang bisa kembali. 7. Pahami Tanda-tanda Makro Perekonomian Mulai mengamati apa yang terjadi dengan perekonomian makro. Indikator-indikator yang harus diamati setiap saat adalah tingkat pertumbuhan ekonomi, kurs rupiah terhadap mata uang asing, laju inflasi, suku bunga perbankan, indeks saham dan tingkat pengangguran. 


\section{Matematika Keuangan}

Menurut Budi Frensidy, definisi untuk cerdas finansial adalah pandai sebagai kas defisit atau sebagai debitur dalam menghadapi bank sekaligus lihai sebagai kas surplus atau investor. Di antara kedua hal tersebut lebih sulit untuk menjadi investor yang lihai. Untuk ini, seseorang harus memahami semua produk keuangan dan investasi yang tersedia disekitarnya, disiplin atau pengendalian rasa takut dan serakah, dan juga menguasai matematika keuangan. Adapun untuk cerdas menghadapi bank, hanya diperlukan dua dari tiga syarat di atas yaitu disiplin atau pengendalian diri dan matematika keuangan. ${ }^{8}$

Seseorang yang cerdas finansial sebagai kas defisit tidak akan terkecoh dengan bunga kredit $0 \%$ atau hitungan bunga flat yang marak ditawarkan, juga akan paham bagaimana pengaruh diskon tunai dan angsuran mulai hari transaksi terhadap bunga efektif. Mereka juga tidak salah persepsi terhadap kartu kredit dan akan menghindari kredit tanpa agunan atau KPR dengan bunga mengambang. Terakhir, yang pintar sebagai kas defisit dapat melakukan sendiri refinancing atau take over ${ }^{9} \mathrm{KPR}$ dan sekaligus menghitung untung ruginya.

Misalkan, pada pertengahan 2009 lalu si B mengambil KPR Rp.200 juta dari sebuah bank dengan bunga efektif $15 \%$ p.a. untuk periode 120 bulan dengan angsuran Rp.3.226.699,-. Dalam kontrak kredit disebutkan bahwa bunga akan dievaluasi setiap tahun dan debitur dikenakan denda $2 \%$ untuk pelunasan lebih cepat. Setelah beberapa bulan angsuran, ternyata bunga pasar terus turun sehingga si B berharap bunga KPR juga ikut dipang-

\footnotetext{
${ }^{8}$ Frensidy, Budi. http:/ / suhaplanner.wordpress.com/2010/08/10/ siasati-tingginya-kpr-bank/. Diunduh 31 Maret 2011.

${ }^{9}$ Refinancing atau pembiayaan kembali utang yang sedang berjalan, caranya adalah dengan mengajukan pinjaman kedua kepada bank yang sama untuk menutup pinjaman pertama dengan maksud mengurangi besar cicilan dengan cara mendapatkan bunga yang lebih kecil atau memperpanjang jangka waktu pembayaran, atau bisa juga keduanya sekaligus. Sedangkan Take Over adalah mengalihkan pinjaman ke bank lain yang bersedia mengambil alih kredit dari bank sebelumnya, tentu saja peminjam akan dikenai biaya-biaya oleh bank yang meng-take over seperti halnya ketika mengajukan peminjaman baru.
} 
kas. Nyatanya, setelah setahun, bunga KPR belum diturunkan dan si B tetap harus mengangsur sebesar Rp.3,2 juta.

Namun, setelah 2 tahun, seiring dengan rendahnya inflasi dan turunnya bunga KPR baru hampir semua bank, si B begitu yakin bunga KPR akan diturunkan. Ternyata, pihak bank tetap tidak mau menyesuaikan, sehingga tentu saja si B menjadi sangat kecewa. Bagaimanakah sebaiknya si B bersikap menghadapi keputusan bank yang tidak fair ini? Banyak nasabah yang dengan pasrah menerima kondisi ini dan tetap membayar angsuran, baik karena ketidaktahuannya maupun karena malas dan tidak mau harus repot-repot berurusan dengan pihak bank. Padahal jika memahami hal-hal semacam ini, sebenarnya ada dua pilihan yang lebih baik bagi si B selain tetap mengangsur, yaitu melunasi sisa utang atau refinancing/take over KPR-nya. Jika si B mempunyai dana, ia dapat melunasi sisa utang KPR-nya. Saldo utang si B setelah 2 tahun adalah Rp.179,8 juta. Dengan adanya denda 2\%, si B harus menyiapkan dana tambahan sebesar Rp.3.596.128,. Sehingga secara keseluruhan yang harus dibayar oleh si B adalah Rp. 183.402.551,-. Akan tetapi bagaimana jika si B tidak mempunyai dana sebesar itu? Salah satu cara ia dapat berusaha melakukan refinancing atau take over yaitu melunasi KPR lama dengan KPR baru dengan suku bunga yang lebih rendah.

Hal yang perlu dilakukan terkait take over adalah dengan mencari informasi mengenai bunga KPR bank lain dan biayabiaya yang dikenakan, juga menanyakan prosedur untuk mengoper KPR dari bank lain. Misalkan, si B mendapatkan bank lain yang bersedia mengambil alih KPR-nya dan menawarkan bunga efektif $12 \%$ p.a. untuk masa 96 bulan. Selain biaya bunga, tentu saja masih ada biaya provisi, administrasi, dan oper kredit yang totalnya, katakan 1\% dari saldo KPR. Si B sudah menghitung KPR baru yang harus diperoleh adalah sebesar Rp. 183,4 juta. Karena ada macam-macam biaya bank yang totalnya Rp.1.834.026,- (1\%) ini, si B hanya akan menerima sejumlah Rp.181.568.526,- jika hanya memohon sebesar kebutuhan dana Rp. 183,4 juta saja. Karena itu, besar KPR baru yang harus diaju- 
kan adalah Rp. 185,2 juta $=$ Rp. 183,4 juta + Rp.1,8 juta. ${ }^{10}$ Dengan dana sebesar ini, KPR lama si B akan dapat dibayar lunas dan yang lebih penting lagi, bahwa si B tidak keluar uang satu rupiah pun untuk proses ini.

\section{Matematika Tingkat Bunga}

Dalam matematika keuangan ada banyak konsep bunga seperti bunga sederhana, bunga majemuk, bunga flat, bunga efektif, bunga diskrit, dan bunga kontinu. Inilah sebabnya matematika keuangan juga dikenal sebagai matematika tingkat bunga. ${ }^{11}$ Bunga majemuk berbeda dari bunga sederhana, demikian juga bunga efektif dan bunga flat, serta bunga diskrit yang tidak sama dengan tingkat bunga kontinu. Yang paling sering ditemui diantara macam-macam suku bunga ini adalah bunga efektif dan bunga flat.

Tanpa memahami kedua macam bunga ini, sangat mungkin seseorang percaya begitu saja tingkat bunga flat yang disampaikan bank untuk kredit motor, mobil, dan pinjaman dana tunai misalnya. Dengan kata lain, bunga efektif pada semua tawaran itu adalah 1,5 kali hingga dua kali bunga flat-nya. Seorang pembeli harus mempunyai kemampuan menghitung tingkat bunga efektif penawaran barang secara kredit dengan benar ketika ada diskon tunai. Hal semacam ini marak terjadi dalam kehidupan sehari-hari.

Cerdas menghadapi bank dengan matematika keuangan itu relevan untuk diketahui dan dipahami siapa saja yang berhubungan dengan bank sebagai debitur karena menggunakan kasus-kasus nyata yang ada. Misalkan contoh berikut, kepada pemegang kartu kredit, sebuah bank menawarkan dana tunai sebesar Rp.2 juta - Rp. 100 juta dengan tingkat bunga 1\% per bulan dalam jangka 6 - 12 bulan dan biaya administrasi $1 \%$ dari

${ }^{10}$ Frensidy, Budi. http:/ / suhaplanner.wordpress.com/2010/08/10/ siasati-tingginya-kpr-bank/. Diunduh 31 Maret 2011.

${ }^{11}$ Frensidy, Budi. http:/ /infogeratis.blogspot.com/2010/04/meskipun-kredit-diskon-tunai-itu.html. Diunduh 31 Maret 2011. 
pinjaman awal, yang harus dibayar di muka. Jika jumlah pinjaman adalah Rp.60 juta, maka cicilan per bulan adalah Rp.10,6 juta selama 6 bulan atau Rp.5,6 juta selama 12 bulan. Dengan menggunakan kalkulator, dapat mengetahui dari mana kedua angka itu diperoleh, yaitu:

$$
\frac{60.000 .000}{6}+(1 \% \times 60.000 .000)=10.600 .000
$$

dan

$$
\frac{60.000 .000}{12}+(1 \% \times 60.000 .000)=5.600 .000 \text {. }
$$

Sepintas tidak ada yang salah dengan hitungan di atas dan peminjam sepertinya memang hanya membayar bunga sebesar $1 \%$ per bulan dengan cicilan bulanan sebesar Rp.5.600.000,- selama 12 bulan. Dalam literatur matematika keuangan, penghitungan bunga seperti di atas disebut tingkat bunga flat. ${ }^{12}$

Istilah tingkat bunga flat muncul untuk pelunasan pinjaman dengan angsuran. Untuk pinjaman yang dilunasi di akhir periode pada satu tanggal tertentu, tidak dengan angsuran, tidak ada istilah tingkat bunga flat dan hanya ada satu istilah yaitu tingkat bunga saja. Tetapi untuk setiap pinjaman dengan pelunasan cicilan, ada dua istilah tingkat bunga yaitu flat dan efektif. ${ }^{13}$ Tingkat bunga flat adalah tingkat bunga yang dihitung berdasarkan plafond kredit tanpa memperhatikan pengubahan sisa pinjaman. Besarnya angsuran, angsuran pokok dan bunga pinjaman adalah tetap dari awal sampai akhir periode. ${ }^{14}$ Walaupun besar pinjaman pokok mengalami penurunan seiring dengan dilakukannya pelunasan secara periodik, besarnya bunga yang dibayarkan adalah sama yaitu $1 \% x 60.000 .000=600.000$. Tingkat bunga flat dalam penawaran bank di atas adalah $1 \%$,

${ }^{12}$ Grandfa. http:/ /id.shvoong.com/social-sciences/1671633-bungacicilan-flat-atau-efektif/\#ixzz1IA8pxTlb. Diunduh 31 Maret 2011.

${ }^{13}$ Grandfa. http://id.shvoong.com/social-sciences/1671633-bungacicilan-flat-atau-efektif/\#ixzz1IA8pxTlb. Diunduh 31 Maret 2011.

${ }^{14}$ Hidayat, Taufik.2010. Financial Planning; Mengelola E Merencanakan Keuangan Pribadi dan Keluarga. Mediakita: Jakarta.

108 Jurnal PHENOMENON, Volume 1 Nomor 1, Juli 2011 
tapi tingkat bunga efektif (tingkat bunga sebenarnya) adalah jauh lebih tinggi.

Sedangkan tingkat bunga efektif adalah kebalikan dari tingkat bunga flat, yaitu tingkat bunga yang dihitung berdasarkan pokok hutang tersisa, sehingga porsi bunga dan pokok dalam angsuran setiap bulan akan berbeda. Pada contoh di atas, dapat dihitung tingkat bunga efektifnya dengan menggunakan komputer, yaitu program Excel. Cukup menginput "=rate(nper,pmt,pv)" ke dalam salah satu sel, yang artinya hitunglah tingkat bunga efektif (i) jika diberikan jumlah periode (nper), besar angsuran (pmt), dan jumlah pinjaman (pv). Untuk contoh di atas, cukup mengetikkan "=rate(12,$5600000,60000000)$ " akan langsung diperoleh tingkat bunga $1,79 \% .{ }^{15}$ Ternyata tingkat bunga efektif untuk kasus diatas adalah 1,79\% dan bukan 1\% seperti yang ditawarkan oleh bank. Hal ini terjadi karena bunga sebesar Rp.600.000 harus dibayarkan setiap bulan sampai akhir periode yaitu 12 bulan, padahal saldo pinjaman sebesar Rp.60 juta hanya pada awal periode sebelum pembayaran angsuran dilakukan. Setelah angsuran pertama, saldo pinjaman menurun menjadi Rp.55 juta, kemudian menjadi Rp.50 juta setelah angsuran kedua dan demikian seterusnya, tetapi bunga yang dibayarkan adalah sama yaitu sebesar Rp.600.000,selama 12 bulan. Inilah yang menyebabkan tingkat bunga efektif hampir dua kali lipat tingkat bunga flat.

Menurut perhitungan yang sebenarnya saldo pinjaman rata-rata selama 12 bulan adalah sebesar

$$
\frac{(60 j u t a+55 j u t a+\ldots+5 j u t a)}{12}=32,5 \text { juta } .
$$

Sedangkan bunga yang dibayar adalah Rp.600.000,- per bulan, sehingga tingkat bunga efektif secara kasar adalah

$$
\frac{600.000}{32.500 .000} \times 100 \%=1,85 \% \text {. }
$$

${ }^{15}$ Grandfa. http:/ /id.shvoong.com/social-sciences/1671633-bungacicilan-flat-atau-efektif/\#ixzz1IA8pxTlb. Diunduh 31 Maret 2011. 
Hitungan kasar ini memang tidak memberikan hasil yang akurat tetapi bisa diperoleh tanpa menggunakan Excel.

Tingkat bunga efektif menjadi lebih besar lagi jika memasukkan biaya administrasi ke dalam perhitungan, sehingga besar pinjaman menjadi hanya sebesar Rp.59,4 juta dan cicilan tetap sama besar. ${ }^{16}$ Dengan Excel, akan didapatkan tingkat bunga efektif adalah 1,95\% per bulan. Tingkat bunga mana yang relevan dan harus dipertimbangkan oleh peminjam? Sudah tentu tingkat bunga efektif karena tingkat bunga inilah yang sebenarnya dibayar peminjam berdasarkan penjelasan di atas.

Kasus lain adalah bank lain juga menawarkan produknya yang sangat kreatif yaitu pinjaman yang harus dilunasi dalam 6 bulan angsuran dengan bunga hanya 5\%. Bunga ini harus dibayarkan pada angsuran pertama. Jika berutang Rp.30 juta, maka harus mengangsur Rp.5 juta setiap bulan selama 6 kali. Khusus untuk angsuran pertama, harus membayar biaya bunga Rp.1,5 juta sehingga angsuran menjadi Rp.6,5 juta. Jika memahami matematika keuangan, nasabah akan langsung menghitung bunga efektif dari produk inovatif bank di atas dan akan menemukan bahwa bunga sebenarnya adalah 1,41\% per bulan atau $16,94 \%$ p.a., dan bukan $5 \%$ atau $10 \%$ p.a. ${ }^{17}$

Besar bunga efektif dapat dihitung jika diketahui kapan angsuran pertama dilakukan, ada tidaknya biaya administrasi, dan ada tidaknya diskon khusus untuk pembelian tunai. Misalkan sebuah Laptop yang berharga tunai Rp. 10 juta ditawarkan secara kredit dengan uang muka 20\% atau Rp.2 juta dan sisanya diangsur dalam 10 angsuran bulanan sebesar Rp. 1 juta mulai 1 bulan lagi. Jika kasus ini diselesaikan, akan diperoleh tingkat bunga efektif adalah 4,28\% per bulan atau 51,3\% p.a. Pembeli kredit semakin dirugikan jika angsuran pertama harus dilakukan pada hari transaksi, seperti yang sering ditemui. Angsuran pertama yang dibayar pada hari transaksi tidak lain adalah uang muka sehingga besar pinjaman menjadi hanya

16 Grandfa. http://id.shvoong.com/social-sciences/1671633-bunga-cicilan-flat-atauefektif/\#ixzz1IA8pxTlb. Diunduh 31 Maret 2011

${ }^{17}$ Frensidy, Budi. Jeli Menghitung Tingkat Bunga Efektif. Bisnis Indonesia, Edisi Minggu 3 Oktober 2010

110 Jurnal PHENOMENON, Volume 1 Nomor 1, Juli 2011 
$10 j u t a-(2 j u t a+1 j u t a)=7 j u t a$. Lamanya angsuran tinggal 9 bulan mulai bulan depan dengan besar angsuran yang sama. ${ }^{18}$ Karenanya, ketika dihitung besar tingkat bunga efektif akan menjadi lebih tinggi yaitu 5,34\% per bulan atau $64,1 \%$ p.a.

Melanjutkan kasus di atas, bagaimana jika pembeli dikenakan biaya administrasi, biaya formulir, biaya aplikasi, atau apa pun namanya, misalkan totalnya sebesar $1 \%$ dari nilai barang? Adanya biaya ini akan menambah beban peminjam. Karena pembayaran biaya ini biasanya dilakukan di muka, bisa dikatakan jumlah pinjaman yang diterima menjadi lebih rendah sementara jumlah kewajiban tetap. Biaya administrasi sebesar $1 \%$ akan menyebabkan jumlah pinjaman hanya sebesar Rp.6,9 juta, sementara nilai variabel lainnya tetap..$^{19}$ Jika dihitung, akan diperoleh tingkat bunga efektifnya adalah $5,67 \%$ per bulan atau $68,1 \%$ p.a.

Bagaimana jika untuk pembelian tunai ternyata diberikan diskon $10 \%$ seperti yang banyak ditawarkan toko untuk meningkatkan penjualan tunai sementara pembelian kredit tidak mendapatkan diskon? Pembeli seharusnya menyadari bahwa harga tunai Laptop sekarang bukan lagi Rp.10 juta tetapi hanya Rp.9 juta karena ada diskon 10\%, sementara syarat-syarat untuk pembelian kredit adalah sama yaitu uang muka $20 \%$, sisanya dilunasi dengan 10 angsuran bulanan Rp.1 juta mulai hari ini, dan ada biaya administrasi $1 \%$. Dengan demikian, total utang untuk pembelian kredit hanya Rp.5,9 juta. Utang sebesar ini harus dilunasi dengan 9 angsuran bulanan Rp.1 juta. Menganggap harga Laptop Rp.10 juta dan utang Rp.6,9 juta adalah kurang cerdas karena Laptop boleh dibawa pulang dengan Rp.9 juta dan pembeli sudah membayar Rp.3,1 juta. Berbekal matematika keuangan, akan diperoleh tingkat bunga efektif adalah 9,40\% per bulan atau $112,8 \%$.p.a. Jelaslah sekarang jika mencicil utang itu lebih sering memberatkan daripada meringankan. ${ }^{20}$

${ }^{18}$ Frensidy, Budi. Jeli Menghitung Tingkat Bunga Efektif. Bisnis Indonesia, Edisi Minggu 3 Oktober 2010

${ }^{19}$ Frensidy, Budi. Jeli Menghitung Tingkat Bunga Efektif. Bisnis Indonesia, Edisi Minggu 3 Oktober 2010

${ }^{20}$ Frensidy, Budi. Jeli Menghitung Tingkat Bunga Efektif. Bisnis Indonesia, 
Perlu dipahami pula ketika ada penawaran dalam hal kredit berupa pembelian suatu barang dengan bunga $0 \%$. Misal ditawarkan sebuah rumah berharga Rp. 300 juta dapat diangsur 60 kali, dengan angsuran bulanan Rp. 5 juta mulai hari transaksi. Untuk pembelian tunai dalam 1 minggu akan diberikan diskon $30 \%$. Berbekal informasi ini, dapat langsung diketahui bahwa tawaran bunga $0 \%$ di atas hanya mitos dan harga tunai sebenarnya adalah $\quad 300$ juta $-(30 \% \times 300$ juta $)=210$ juta $_{21}$ Karena itu, jika dihitung lagi bunga sebenarnya atau tingkat bunga efektif adalah sebesar 1,25\% per bulan atau $15 \%$ p.a. dan bukannya $0 \%$ seperti yang ditawarkan.

\section{Simpulan}

Kecerdasan finansial penting bagi semua orang berapapun pendapatannya. Karena itu diperlukan pengetahuan yang cukup sehingga dapat meraih skor kecerdasan financial menjadi satu bahkan lebih. Dengan memahami semua produk keuangan dan investasi yang ada, disiplin atau pengendalian rasa takut dan serakah, dan juga menguasai matematika keuangan, maka seseorang dapat meningkatkan skor kecerdasan finansialnya. Yang selanjutnya, para nasabah dan juga pembeli tidak akan terjebak oleh berbagai macam trik yang ditawarkan oleh bank maupun penjual. Sehingga dapat berpikir lebih rasional dan logis dalam membuat suatu keputusan yang berkaitan dengan pengelolaan keuangannya.

Edisi Minggu 3 Oktober 2010

${ }^{21}$ Frensidy, Budi. Jeli Menghitung Tingkat Bunga Efektif. Bisnis Indonesia, Edisi Minggu 3 Oktober 2010

112 Jurnal PHENOMENON, Volume 1 Nomor 1, Juli 2011 


\section{DAFTAR PUSTAKA}

Arifin, Bustanul. http://bustanularifin.wordpress. com/2006/02/28/ kecerdasan-finansial/. Diunduh 5 April 2011

Frensidy, Budi. Jeli Menghitung Tingkat Bunga Efektif. Bisnis Indonesia, Edisi Minggu 3 Oktober 2010.

Frensidy, Budi. http://suhaplanner.wordpress. com/2010/08/10/ siasati-tingginya-kpr-bank/. Diunduh 2 April 2011.

Frensidy, Budi.http://infogeratis.blogspot.com/2010/04/ meskipun-kredit-diskon-tunai-itu.html. Diunduh 31 Maret 2011.

Grandfa.http:/ / id.shvoong.com/social-sciences/1671633-bunga-cicilan-flat-atau-efektif/\#ixzz1IA8pxTlb. Diunduh 31 Maret 2011.

Hidayat, Taufik. 2010. Financial Planning; Mengelola \& Merencanakan Keuangan Pribadi dan Keluarga. Mediakita: Jakarta.

Supriyono, Iman. http://www.snfconsulting.com/artikel03. html. Diunduh 5 April 2011.

Tanuwidjaja, William. 8 Intisari Kecerdasan Finansial. Penerbit MedPress, Yogyakarta. 